\title{
Spatiotemporal analysis of urban growth on forest and agricultural land using geospatial techniques and Shannon entropy method in the satellite town of
} Ethiopia, the western fringe of Addis Ababa city

Kiros Tsegay Deribew(D)

\begin{abstract}
Rapid conversion of conserved land and cropland to non-agricultural purposes is threatening the ecological areas and dominant agricultural activities that are the main sources of livelihood in urban fringe areas of Addis Ababa City. The combinations of government policy, socioeconomic, demographic dynamics, and biophysical triggers have driven such transformation. However, the recent fast urban expansion and infrastructural development could have accelerated the severity and rate at which urban growth impacts the ecosystem and fertile agricultural land. Yet, little attention is given about their impacts on forest and farming communities in the western fringe areas of Addis Ababa during the recent past. This study, therefore, aimed at quantifying and analyzing the trends of the urban growth and its impacts on flora and agricultural land in Sebeta-Awas town using an integrated GIS tool, remote sensing technique, and Shannon entropy method. Landsat TM of 1986, ETM+ of 2002, and OLI of 2019 were used to produce land use/land cover (LULC) classes. Object-based classification technique was carried out to generate the LULC and to measure the changes in the urban land-use class within the satellite town in the year 1986, 2002, and 2019. Shannon entropy method was applied to model study area's urban sprawl, growth trend, and spatial change. Over the past three decades (1986-2019), Sebeta-Awas town has experienced severe urban sprawl following lack of proper development control and management. The annual urban growth rates of 1.2, 5.5, and $\sim 15 \%$ for the periods of 1986, 2002, and 2019, respectively were obtained mainly at the expenses of agricultural land (25.48\%) and forest land (16.6\%), catalyzed urban sprawl which finally led to serious deforestation and reduction in rural farmland. The findings indicate that the average of entropy index increased from 0.02 in the year 1986 to 0.996 in the year 2019, indicating more dispersed urban growth to the outskirts, and spatially indicating anticlockwise shifting. In this regard, more than $90.2 \%$ of forest loss due to agricultural encroachment, built-up area expansion, and construction was widely observed in Sebeta and Alem Gena areas, of course, Northeast zone in this study. It is concluded that deforestation and continual evacuation of farming communities in the urban fringe areas (Continued on next page)
\end{abstract}

Correspondence: crosstsegaye@gmail.com

Department of Geography and Environmental Studies, Jimma University, P.O. Box 378, Jimma, Ethiopia

\section{Springer Open}

(c) The Author(s). 2020 Open Access This article is licensed under a Creative Commons Attribution 4.0 International License, which permits use, sharing, adaptation, distribution and reproduction in any medium or format, as long as you give appropriate credit to the original author(s) and the source, provide a link to the Creative Commons licence, and indicate if changes were made. The images or other third party material in this article are included in the article's Creative Commons licence, unless indicated otherwise in a credit line to the material. If material is not included in the article's Creative Commons licence and your intended use is not permitted by statutory regulation or exceeds the permitted use, you will need to obtain permission directly from the copyright holder. To view a copy of this licence, visit http://creativecommons.org/licenses/by/4.0/. 
(Continued from previous page)

due to rapid urban expansion in the name of investment and infrastructural development is expected to be

worsened in the near future unless strong policy revision and management actions are undertaken.

Keywords: Concentric rings, Entropy index, Urbanization, Urban sprawl

\section{Introduction}

Urbanization is the rapid proportion of the population living in urban areas, and urban expansion is a further physical expansion (spatial extent) of already existing urban centers (Alig and Healy 1987; Cheng and Masser 2003; Wakode et al. 2014). The world has experienced rapid urbanization and slum proliferation in the twentieth-first century (Singh 2014; Kamusoko and Gamba 2015; Subasinghe et al. 2016; Liu et al. 2019). United Nation indicated that only $13 \%$ of the world population lived in urban areas in 1990. This has also been heightened to 30\% by the mid of the 1990s. However, over the past two decades, the number of urban dwellers has already dramatically surpassed its peripheries counterparts. In this regard, the global population of the urban share would grow to $68 \%$ by 2050 (UN 2015). In the same projection, Africa and Asia are projected to account for nearly $90 \%$ of the world's urbanization rates in the coming three decades. Even though, there are considerable variations in urbanization rates and shares among less and more developed world, in the developing world ( $4 \%$ a year) in general is urbanizing much faster than in developed countries (Soubbotina 2004; Kiamba 2012). In the developed world, urbanization rates are constant or decline due to regular settlement patterns and relatively stable population growth. In contrast, developing countries are still industrializing and urbanizing, so attract even more population from rural areas where population growth rate is relatively higher (3\% a year), and experiences null job opportunities. Hence, unlike the developed world where urbanization process is triggered by industrialization, the urbanization process in developing countries is characterized by demographic changes such as rapid natural population growth and rural-urban migration, which is, in turn, stimulated by urban growth. Despite its socio-economic significance, urbanization threatens biodiversity, and ecosystems, this has led to ecological depletion and ecosystem disruptions in the ecologically important areas (Liao et al. 2018; Wang et al. 2018; Deribew and Dalacho 2019).

Urbanization in Ethiopia is characterized by a low level of urbanization even by African standard, where only $18 \%$ of populations live in the urban area, of which $23 \%$ are living in metropolitan Addis Ababa (PCC 2008; CSA 2015). Yet, Addis Ababa has recorded a relatively high growth rate of urban population ( $4 \%$ annually); double that of rural areas. This was due to the high population growth rate $(2.75 \%)$, accompanied by a high rate of rural-urban and urban-urban migration (Lohnert 2017). Nevertheless, Teller and Assefa (2010) and Puertas and Henriquez (2014) state that a high growth rate and demographic shift are not often accompanied by a development in socioeconomic services and infrastructure, and economic and employment capacity of the urban centers to support the growing population.

Addis Ababa City is a nodal point perceived to create job opportunities and improve socio-economic activities in the country (Mohamed et al. 2019). Studies highlighted that the city has been rapidly expanding towards its peri-urban areas to accommodate the ever-increasing population, settlements, and infrastructural developments (Samson 2009; Leulsegged et al. 2011). This rapid outward urban expansion due to the increasing urban population marked that peri-urban areas are growing much more quickly than the formal urban center. However, such unprecedented population growth coupled with colossal developmental activities in its undesirable forms in urban fringe has negative impacts on the ecosystem, natural resources, human health and has caused some socioeconomic problems (Mohamed et al. 2019). Such phenomena drive the land cover transformation pattern which proceeded to ecological deterioration, poverty, urban sprawl, informal settlements, urban informality, unstructured and unplanned development mainly in the fringe of the city (Abebe et al. 2019; Deribew and Dalacho 2019). The vicinities of Addis Ababa city have an exceptionally experienced intense level of landscape conversion mainly due to demographic pressure (rural-urban and urban-urban migration) attributed to a high rate of urban expansions and infrastructural developments (FZSeP 2011).

The influx of unemployed people looking for job opportunities due to massive investment in industries, infrastructural, and real estate developments in the urban fringes of Addis Ababa has brought drastic changes in the landscape. Studies revealed that in the central highlands of Ethiopia close to Addis Ababa have seen a rapid expansion of agricultural land at the expense of forest land over the last half-century (Minta et al. 2018; Deribew and Dalacho 2019). The former and latter studies reported that forest land declined by 73 and $50 \%$ of the total during 1957-2014 and 1957-2017 in Dendi-Jeldu mountains and North-east Addis Ababa city, respectively in the central highlands of Ethiopia. Though both authors reported a massive loss of forest cover to cultivated land, pastureland, and settlements, the rate at which farmland increase over time had declined mainly due to a shortage of available suitable land for cultivation. The 
same pattern has also been observed in South Wollo, North-central Ethiopia (Rosell et al. 2017). However, the latter study showed that in terms of gains settlements/built-up areas obtained $7.7 \%$ of the total area, of which $7.2 \%$ obtained from both agricultural land and forests in the North-eastern fringe of Addis Ababa. The high rate of urban expansion and infrastructural developments due to shift of demographic pressure following the new master plan of Addis Ababa and outward migration of urban poor people to the eastern margin of the city in search of employment opportunities in real-estate developments, industries, and infrastructural developments were found to be the main drivers. Similarly, the 24 years report (1986-2010) conducted by Leulsegged et al. (2011) showed that $\sim 121 \mathrm{~km}^{2}$ of landscape mainly forest and croplands were converted into built-up areas. This may have far-reaching impacts on the peri-urban ecosystem and livelihood economy.

Also, the recent expansion of residential, commercial, industrial areas, and infrastructural developments, accompanied by government investment policy was considered to be the major driver of landscape change (Deribew and Dalacho 2019). Yet, little attention is given about their influences on flora and rural farmland in the western fringe areas of Addis Ababa during the recent past. Hence, effective and efficient planning of satellite town growth and undesirable land-use changes and its impact on the forest and agricultural land requires information about growth trends and patterns amongst other important information. In this regard, the recent integration of GIS with the Shannon entropy method has been useful in the analysis of urban growth trends and predictions (Shenbagraj et al. 2019). This method is a computational model that provides the urban growth trend (how much?), direction (from/to which direction/s?), and location of change (where?) analysis with greater specificity than other urban indicator models (Rahman et al. 2011; Singh et al. 2019). In the study area, as urban areas have changed rapidly over the last decade, analysis of urban dynamics has become increasingly common because they can be produced rapidly and are easy for comparative analysis. This study, therefore, aimed at quantifying and analyzing the urban growth-ecology nexus which is driving forest and agricultural land loss in Sebeta-Awas town using an integrated GIS tool, remote sensing technique, and Shannon entropy method.

\section{Data and methods}

\section{Study area}

The study area, Sebetea-Awas town in the western fringe areas of Addis Ababa, extends between $8^{\circ} 35^{\prime}$ to $9^{\circ} 05^{\prime} \mathrm{N}$ and $38^{\circ}$ $24^{\prime}$ to $38^{\circ} 45^{\prime}$ E, covering an area of 87,600 ha (Fig. 1). The satellite town occupies a very large built-up population, migrant, and evacuated farming communities. It includes fastgrowing towns: Sebeta, Alem Gena, Awash, Tefki, and Boneya which cover more than $90 \%$ of the total population of the study area. The topography of the study area is characterized by a plain with some mountain ranges in the northern part with the altitude ranging from $1808 \mathrm{~m}$ to $3381 \mathrm{~m}$ above sea level.

The study area was among the most ecological destination area in peri-urban satellite towns of Addis Ababa City. The natural vegetation of the study area belongs to the remnant Afromontane forest of the Ethiopian highlands which had survived millennia of human exploitation and land conversions (Friis and Breugel 2010). The forests are found in churchyards, riverbanks, protected areas, and steep slopes. The remnant forest is a mixed dry Afromontane forest which is scattered in the upper canopy stratum of inaccessible and protected areas.

According to the Finfine Zone Socioeconomic profile (FZSeP 2011), the population growth is very rapid due to natural increase, rural-urban migration, and urban-urban migration. During the first population census (1984), the population in the study area was more than 50,000 though there is scarce demographic data of the peripheries. In addition to this, the total population of the study area was 0.12 million in 1994 and it grew over 0.17 million in 2005 and increased by almost two-fold to 0.29 million in 2013 (CSA 2015). Similarly, the authority also reported that following surge of the population to the town's current population almost doubled its 2007 size by crossing over 0.35 million in 2018. However, there are no still true statistics of the current population due to the rapid immigration of peoples from the centers and across the rural areas in the country. It is among very few urban fringe areas in the frontier of Addis Ababa where major urban expansions are occurring. So with this fast-growing number of urban population trends, the municipality has been faced with mammoth challenge for the peri-urban ecological sites and agricultural sector. The study area is a satellite town which attracts massive public residential constructions, investments, factories, and institutions to fulfill the demand of the residents and Addis Ababa populations.

The region is known for its high wheat, barley, pulses, teff, vegetables, and livestock productions and supplying for domestic market consumption particularly to Addis Ababa inhabitants, and for factories. Nonetheless, the forest land and fertile agricultural land have been replacing by various real estate developments, industries, factories, and infrastructural developments which in turn attract several thousands of newcomers to the area.

\section{Research methods and design}

This study applied remote sensing, Shannon entropy, software ArcGIS 10.2, and ERDAS Imagine 2014 to assess the spatial extent of peri-urban expansions and urban growth trends since the mid of the 1980s. In addition, an interview with thirty key informants from the aforementioned towns during field observation was conducted to extract qualitative information about the perception of dislocated farmers in the study area. 


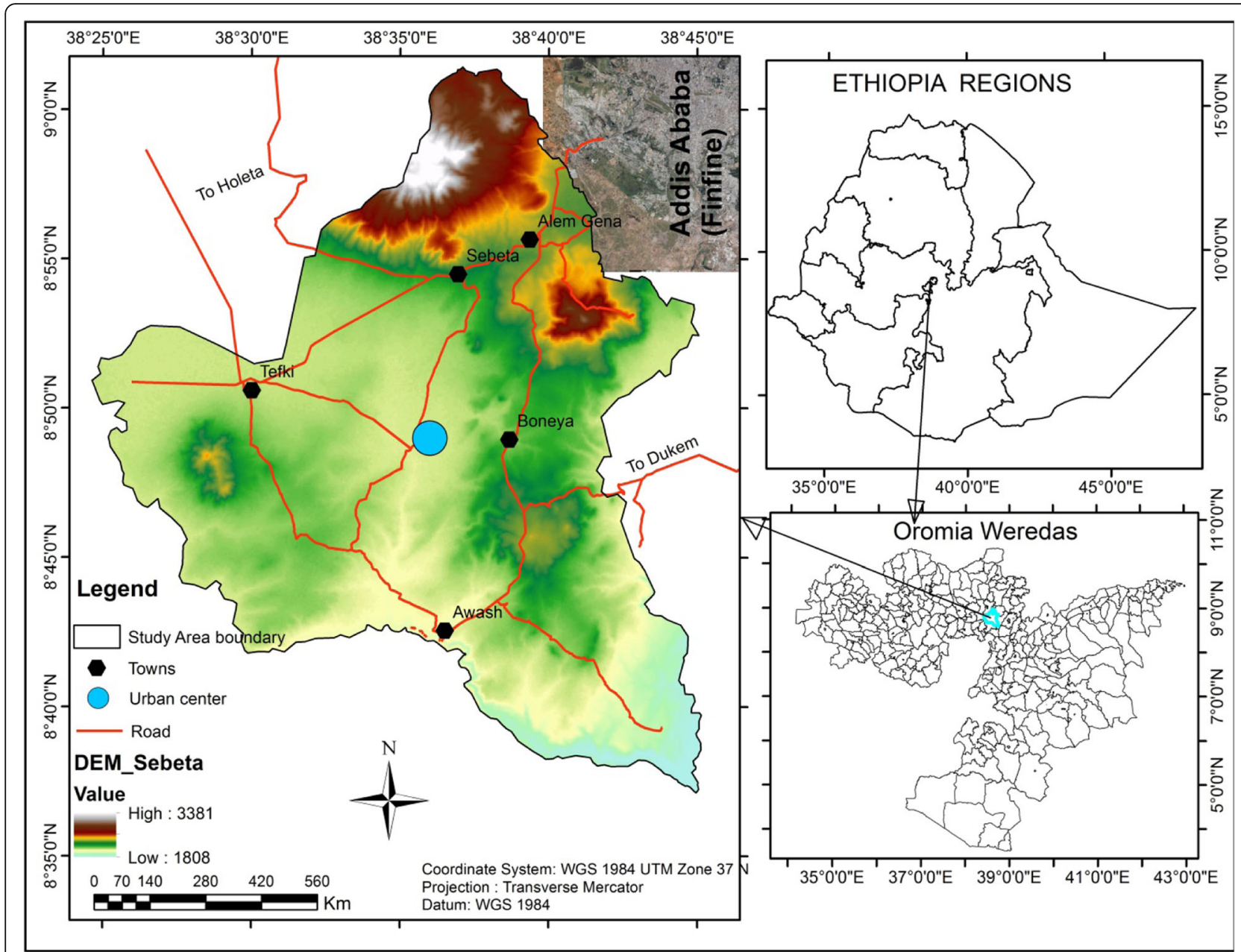

Fig. 1 Location and topography of the study area

\section{Data type and sources}

\section{Satellite imageries and ancillary data}

In this study, Landsat TM of 1986, ETM+ of 2002, and L8 (OLI) of 2019 were used to extract land-use and land-cover information for Sebeta-Awas town (Table 1). All Landsat imageries obtained free of charge from the United States Geological Survey (USGS) via https:// earthexplorer.usgs.gov/ were cloud-free. ASTER global digital elevation model (GDEM $30 \mathrm{~m} \times 30 \mathrm{~m}$ ) was freely accessed from US NASA to grasp model elevation of the study area. Topographic maps at the scale of 1:50000 dated in 1984/86 were obtained from Geospatial Information Agency (GIA) to check the position of satellite imageries.

\section{Data analysis}

Land satellite image data pre-processing, development of image classification and referencing points

Although the United States Geological Survey (USGS) data center freely provided pre-processed Landsat scenes, pre-processing techniques were applied to minimize the distortions in hilly areas of the study area. Hence, all Landsat imageries were topographically corrected using the non-Lambertian model for the Ccorrection of Teillet et al. (1982) with PG-STEAMER 4.2 software. A technique developed by Chander et al. (2009) was considered to correct the radiometric correction (Eqs. 1 and 2). Likewise, we also consulted techniques developed by Richter et al. (2006) and Vermote and Saleous (2006) for atmospheric correction of satellite images in ERDAS imagine 2014 software.

$$
\left.\mathrm{L} \Lambda=\left[\left(\frac{\text { LMAX } \Lambda-\text { LMIN } \Lambda}{\text { QCALMAX }- \text { QCALMIN }}\right) *(\text { QCAL }- \text { QCALMIN })+\text { LMIN } \Lambda\right)\right] \ldots \ldots \ldots . . .
$$

$$
\mathrm{P} \Lambda=\frac{\pi * \mathrm{~L} \Lambda * d^{2}}{\operatorname{ESUN} \lambda * \cos \theta \mathrm{s}} \ldots \ldots \ldots \ldots
$$


Table 1 Description of data type and sources

\begin{tabular}{|c|c|c|c|c|}
\hline & 1986 & 2002 & 2019 & Purpose \\
\hline Satellite (sensor) & Landsat TM & Landsat ETM+ & Landsat OLI & LULC classification \\
\hline Sources & Earth explorer & Earth explorer & Earth explorer & \\
\hline Resolution & $30 \times 30 \mathrm{~m}$ & $30 \times 30 \mathrm{~m}$ & $30 \times 30 \mathrm{~m}$ & \\
\hline Path/row & $168 / 054$ & $168 / 054$ & $168 / 054$ & \\
\hline Acquisition date & 03/26/1986 & $02 / 26 / 2002$ & 02/01/2019 & \\
\hline Sun elevation & 53.89042105 & 53.91455582 & 51.36869550 & \\
\hline Sun azimuth & 98.39366733 & 118.06159253 & 131.97553411 & \\
\hline Solar zenith angle & 36.10957895 & 36.08544418 & 38.6313045 & \\
\hline Earth-Sun distance & 0.9975825 & 0.9901226 & 0.9853171 & \\
\hline Cloud cover & Free (study area) & Free & Free (study area) & \\
\hline Image quality & 9 & 9 & 9 & \\
\hline Google earth image & Yes, 1986 & Yes, 2002 & Yes, 2019 & Ground truth \\
\hline Ancillary data & Sources & & & Purpose \\
\hline Road & CSA & & & Proxy for \\
\hline Population (since 1984) & CSA \& Municipality & & & Growth trend \\
\hline Other socio-economic data & Municipality & & & Ancillary \\
\hline
\end{tabular}

After having successfully pre-processed, a land-use classification scheme was carried out considering the USGS classification scheme (Anderson et al. 1976). In addition, field interviews and observations were conducted to collect information from stakeholders. Accordingly, four major land-use and land-cover classes namely built-up areas, urban-peri-urban agriculture, open land, and forest land were identified (Table 2). For this classification, about 520 sampling points were collected from historical Google Earth images of which 320 and 200 points were used for classification and reference, respectively. Finally, the object-based classification technique was applied to minimize the spectral signature confusion of land-use and land-cover classes.

The classified LULC categories with referenced data were compared to evaluate the degree of accuracy output (Lillesand et al. 2008). In this regard, the overall, producer, and user accuracies and Kappa coefficient (khat) were computed after consulted (Lillesand et al. 2008).

\section{Spatial extent, trends and rates of urban expansions}

The percentage $(P)$ of transitions in land-use and land-cover was computed by applying equation 3 . Using the Boolean operation method, built-up area was extracted from other classes in the ArcGIS environment. Similarly, Eq. 4 formalizes how to compute annual rate $(r)$ of urban growth at different periods, the methods outlined in (Puyravaud 2003). Moreover, gross gains $(g)$ and gross losses $(l)$ were computed from the existing persistence classes.

$$
\begin{aligned}
& \mathrm{P}=\left[\left(\frac{\mathrm{A} 2-\mathrm{A} 1}{\mathrm{~A}_{1}}\right) * 100\right] \ldots \ldots \ldots \\
& \mathrm{r}=\left[\left(\frac{100}{\Delta t}\right) * \ln \left(\frac{A_{2}}{A_{1}}\right)\right] \ldots \ldots \ldots
\end{aligned}
$$

Where $A_{1}$ and $A_{2}$ are the area coverage of a land cover at $\boldsymbol{t}_{\boldsymbol{1}}$ and $t_{2}$. $\boldsymbol{l n}$ is the base of the natural algorithm function.

\section{Analysis of the urban sprawl}

As to Sudhira et al. (2004) and Rahman et al. (2011), the integration of GIS tool, Landsat imageries, and Shannon entropy methods are techniques to model and monitor rapid urban expansions mainly in a rapid population growth cities. Shannon's urban entropy among different metrics is widely consulted in many studies to quantify urban expansion in a fast-growing region (Kumar et al. 2007; Deka et al. 2012).

The approach measures the degree of spatial concentration and dispersal of built-up areas over time (Singh et al. 2019). In this study, at 1,2 , and $3 \mathrm{~km}$ concentric distances were used and analyzed separately. However, none of them provided clear information about the distribution except the former interval, i.e., $1 \mathrm{~km}$. In line with this using the confirmed concentric interval $(1 \mathrm{~km})$ the potential Modifiable Area Unite Problems (MAUP) effects were checked, and the results showed insignificant MAUP problems. Hence, for this study, twenty-five concentric shield rings at an interval of $1 \mathrm{~km}$ were designed from the core of the town denoted by letter "A" up to $25 \mathrm{~km}$ denoted by letter "Y" for Shannon entropy 
Table 2 Contingency table for the year 2019 classified map

\begin{tabular}{|c|c|c|c|c|c|c|c|}
\hline & & \multicolumn{4}{|c|}{ Reference data 2019} & \multirow[b]{2}{*}{ Row total } & \multirow[b]{2}{*}{ UA (\%) } \\
\hline & & $\overline{\mathrm{AL}}$ & $\mathrm{BA}$ & $\mathrm{OL}$ & UF & & \\
\hline \multirow[t]{7}{*}{ Classified data } & $\mathrm{AL}$ & 50 & 0 & 0 & 0 & 50 & 100.00 \\
\hline & BA & 1 & 49 & 1 & 0 & 51 & 96.08 \\
\hline & $\mathrm{OL}$ & 1 & 0 & 50 & 0 & 51 & 98.04 \\
\hline & UF & 0 & 0 & 0 & 48 & 48 & 100.00 \\
\hline & Column total & 52 & 49 & 51 & 48 & 200 & \\
\hline & PA (\%) & 96.15 & 100.00 & 98.04 & 100.00 & & \\
\hline & & & & & $K=0.98$ & $.5 \%$ & \\
\hline
\end{tabular}

Where $A L$ agricultural land, BA built-up area, OL open land, UF urban forest. Diagonal elements in italics indicate LULC classes are classified correctly

calculations. These were further divided into four zones: northeast, northwest, southeast, and southwest, to identify urban sprawl direction and growth in individual zones.

Consequently, the average entropy values from the town center for all twenty-five zones, and the above four zones were computed to evaluate the pattern of urban growth over time. In this regard, the Shannon entropy $\left(H_{\mathrm{n}}\right)$ technique developed by Yeh and Li (2001) was consulted to measure the patterns of urban growth (Eq. 5). The notation of $P_{\mathrm{i}}$ is the probability of variable occurring in the $i$ th zone and $n$ is the total number of zones. In line with this, change entropy values $\left(\Delta H_{\mathrm{n}}\right)$ between initial time $\left(t_{1}\right)$ and final time $\left(t_{2}\right)$ was applied to indicate the magnitude of change of urban sprawl in Eq. 6 .

$$
\begin{aligned}
& H \mathrm{n}=\sum_{i=1}^{n} P_{i} \log _{e}\left(P_{i}\right) \ldots \ldots \ldots \ldots . \\
& \Delta H \mathrm{n}=H \mathrm{n}(t+1)-H \mathrm{n}(t) \ldots \ldots
\end{aligned}
$$

Finally, field verification and validation were conducted to recheck the model output and growth of builtup areas concerning the distance from the town center.

\section{Results}

\section{Accuracy assessment}

The error matrix report for 1986, 2002, and 2019 classified maps are presented in Table 2. Accordingly, a value of $98.5 \%$ overall accuracy and $0.98 \%$ of Kappa coefficient value for 2019 classified map was recorded. Likewise, overall accuracies of $95.5 \%$ and $97.5 \%$, and associated khat values of 0.94 and 0.97 were obtained for the reference years of classified maps of 2002 and 2019, respectively. Landis and Koch (1977) and Congalton and Green (2009) suggested that the Kappa statistics of a value greater than 0.8 indicate a strong agreement while a value ranging between 0.6 and 0.8 represents a substantial agreement between the reference data and classified maps. Accordingly, the error matrix report for all study periods presented classified maps met the accuracy requirements and ready to conduct built-up area dynamics (Anderson et al. 1976).

\section{Spatial extent, trends, and rates of urban expansions}

Figure $2 \mathrm{a}-\mathrm{c}$ presents the land use/land cover maps of the study area for the years 1986, 2002, and 2019. Both agricultural land and urban forest were the dominant classes in 1986 roughly covering over $55.25 \%$ and $37.32 \%$ of the landscape, respectively while in 2002 urban forest had lost its second position to built-up areas $(8.78 \%)$ (Table 3$)$. Even though agricultural land kept its dominance (66.72\%) until 2002, it drastically lost its position to built-up areas (43.35\%) in 2019.

The transitions of landscape categories since the mid1980 s in three-span study periods are indicated in Table 3. The trends of agricultural land, open land, and forest land were decreased throughout the study periods except for the former class in 2002 but the rate of decrease was different. The former class expanded to forest area following rapid urban expansion near to town center on croplands in 2002. However, a built-up area rapidly replaced agricultural land following massive constructions, investments, and factories in 2019. Generally, the built-up area has significantly increased which finally resulted in deteriorating forest resources over the past three decades in the study area. The same experience in the study area has also has been confirmed that human disturbances due to human settlement expansion and agricultural encroachment towards key ecological areas endanger endemic and endangered species in Merhabete district, Central highlands of Ethiopia (Abrha et al. 2017).

\section{Percentage change and rate of built-up area expansion}

In the first study period (1986-2002), the built-up areas exhibited a net positive change of $15.2 \%$ while a net decline of urban forest land $28.54 \%$ (Table 3). Built-up areas recorded total gains of $15.58 \%$ of which $10.17 \%$ from agricultural land and 4.95\% from forest land (Fig. 3). Similarly, agricultural land gained $21.4 \%$ of forest land. During this period, built-up areas increased at an annual rate of $\sim 1.2 \%$ with substantial gains from the two crucial classes 


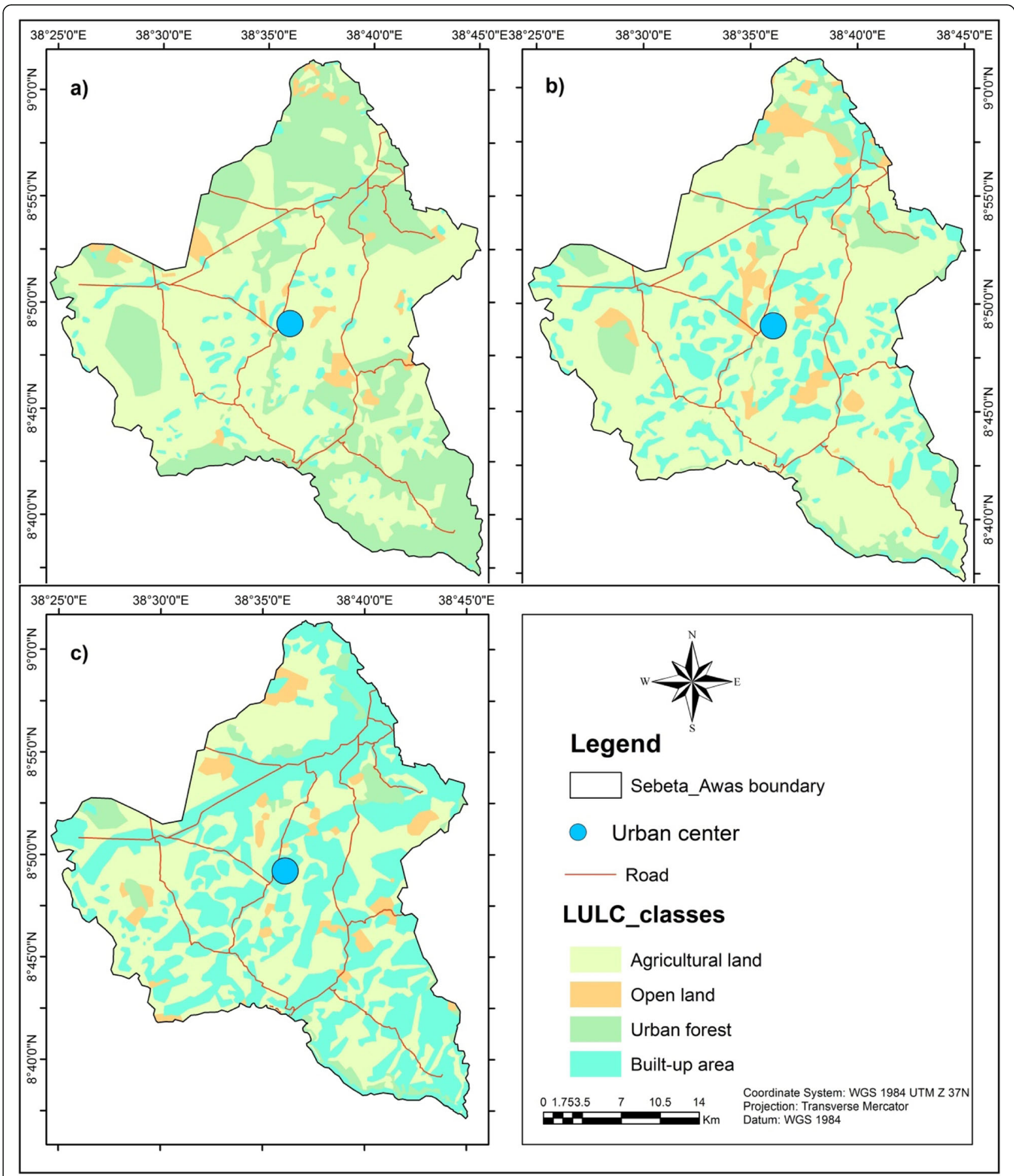

Fig. 2 Land use/land cover thematic map of the study area a (1986), b (2002), and c (2019)

(agricultural land and forest land). In terms of persistence considering their areal coverage, only built-up areas avoid a loss to other classes and retain its original cover (4.2\%) though agricultural land persisted (43.61\%) but lost
$10.17 \%$ and $1.1 \%$ to built-up areas and open land, respectively.

In the second study period (2002-2019), built-up areas and agricultural land showed a comparably higher 
Table 3 Land use/land cover transitions for each study span periods in \%

\begin{tabular}{|c|c|c|c|c|c|c|c|}
\hline & $\mathrm{AL}$ & BA & $\mathrm{OL}$ & $\mathrm{F}$ & Total & Losses & Net change \\
\hline \multicolumn{8}{|c|}{$1986 / 2002$} \\
\hline$A L$ & 43.61 & 10.17 & 1.06 & 0.40 & 55.25 & -11.63 & 11.47 \\
\hline BA & 0.36 & 4.19 & 0.01 & 0.00 & 4.56 & -0.37 & 15.21 \\
\hline $\mathrm{OL}$ & 1.35 & 0.46 & 0.81 & 0.25 & 2.88 & -2.06 & 1.86 \\
\hline$F$ & 21.40 & 4.95 & 2.85 & 8.13 & 37.32 & -29.20 & -28.54 \\
\hline Total & 66.72 & 19.77 & 4.74 & 8.78 & 100.00 & -43.26 & 0.00 \\
\hline Gains & 23.10 & 15.58 & 3.92 & 0.65 & 43.26 & 0.00 & \\
\hline \multicolumn{8}{|c|}{$2002 / 2019$} \\
\hline $\mathrm{AL}$ & 38.62 & 25.00 & 2.46 & 0.64 & 66.72 & -28.10 & -23.37 \\
\hline $\mathrm{BA}$ & 0.63 & 19.02 & 0.10 & 0.02 & 19.77 & -0.75 & 27.91 \\
\hline $\mathrm{OL}$ & 1.92 & 1.61 & 1.17 & 0.03 & 4.74 & -3.56 & -0.28 \\
\hline F & 2.17 & 2.06 & 0.72 & 3.83 & 8.78 & -4.95 & -4.26 \\
\hline Total & 43.35 & 47.68 & 4.46 & 4.51 & 100.00 & -37.36 & 0.00 \\
\hline Gains & 4.73 & 28.66 & 3.28 & 0.69 & 37.36 & 0.00 & \\
\hline \multicolumn{8}{|c|}{ 1986/2019 } \\
\hline $\mathrm{AL}$ & 28.45 & 25.48 & 1.05 & 0.27 & 55.25 & -26.80 & -11.90 \\
\hline BA & 0.20 & 4.33 & 0.02 & 0.00 & 4.56 & -0.23 & 43.12 \\
\hline $\mathrm{OL}$ & 1.09 & 1.21 & 0.31 & 0.26 & 2.88 & -2.57 & 1.58 \\
\hline $\mathrm{F}$ & 13.61 & 16.66 & 3.08 & 3.97 & 37.32 & -33.35 & -32.81 \\
\hline Total & 43.35 & 47.68 & 4.46 & 4.51 & 100.00 & -62.94 & 0.00 \\
\hline Gains & 14.90 & 43.35 & 4.15 & 0.54 & 62.94 & 0.00 & \\
\hline
\end{tabular}

The diagonal elements in italics indicate the unchanged LULC classes

magnitude of net change $(+27.91 \%$ and $-23.37 \%$, respectively) but to opposite directions. Built-up areas increased at an annual rate of $5.5 \%$ with significant gains $25 \%$ from agricultural land and substantial gains $2.06 \%$ from forest land, which was high above the national urbanization rate of $4 \%$ (Fig. 3). This might be due to socioeconomic, political, infrastructural developments, and demographic factors.

Over the last three decades (1986-2019), rapid change in built-up areas especially informal settlements and public residential and mixed residential areas showed a net positive increase from $27.91 \%$ during $2002-2019$ to 43.12\% during 1986-2019. In this period, built-up area increased by four times as compared with the previous period ( $15.5 \%$ per annum) significantly gains $25.48 \%$ and $16.66 \%$ from agricultural lands and urban forest, respectively (Fig. 3). In contrast, built-up areas rejected being converted to or loss to these and other classes, this possibly due to massive construction of new houses informal settlements along river banks, forests, and far on agricultural lands. This indicates the urban area that has grown approximately four and three times over the past three decades. Consequently, Fig. 3 confirms the rapid rate of urbanization and settlements on agricultural lands and urban forests further triggered the economic, political, ecological, and the environment in general (Abebe et al. 2019; Deribew 2019).

However, unlike other studies conducted in big cities, metropolis, megalopolis, and conurbation in this study (small city), the designation of $1 \mathrm{~km}$ and four quadrants have been confirmed that does not subject to potential modifiable area unit problems (MAUP). In this regard, the researcher genially consulted literature and urban planners on the potential MAUP in the study area. The results found at 2 and $3 \mathrm{~km}$ distances of concentric rings did not provide clear information following the distribution of small growth villages and towns. Following this, 1 kilometer $(1 \mathrm{~km})$ concentric has been designed and comprehends the nature of urban growth in the study area which was initially slow later being swift to the outskirt of the urban center. Hence, at $1 \mathrm{~km}$, concentric findings were far better compared with 2 and $3 \mathrm{~km}$ concentrics. Therefore, based on the analyzed result, it is concluded that MAUP are not impacted.

\section{The magnitude and shifting of urban growth}

The built-up area in 1986 was $4.6 \%$ of the total and increased to $19.77 \%$ in 2002 and finally heightened to $47.68 \%$ by the year 2019 . Figure 4 shows built-up area zones in concentric rings in 1986, 2002, and 2019. The rings were covered up to $25 \mathrm{~km}$ (" $\mathrm{A}$ " in the center to " $\mathrm{Y}$ " at the periphery) from the center, covering the entire study area. Figure 5 (overall study area) indicated the distribution of the percentage of the built-up area within each of the rings for the years 1986, 2002, and 2019. It indicates the temporal change of built-up areas over the past three decades (1986-2019). In this regard, urban growth was higher close to the center (B-E and F) then after drastically declining to the periphery shown in 1986. Similarly, in the year 2002, the magnitude of urban growth was increased from where the built-up area stoppage in 1986 and started to decline to the remote periphery (S to $\mathrm{Y}$ ). However, in 2019, urban growth was rapidly increased to the periphery ( $\mathrm{F}$ to $\mathrm{Y}$ ) than former study periods.

Figure 6 indicates the percentage of zone-wise distribution of built-up areas within each concentric ring over the past three decades in the study area. The result revealed a heterogeneous distribution of built-up areas in all zones. In the former period (1986), colossal built-up areas in all four zones were concentrated close to the urban center of the town (A) but gradually decline towards the outer parts of the town. However, in the second study period (2002), urban growth was significant around the center in all zones except in the northeast zone at $500 \mathrm{~km}$. This was later increased to the outskirts though the percentage at which they grew was different. In contrast to 2002, the growth of new urban areas to the outskirt of the center on cultivated land and forest land was terrifically observed in all zones in the recent 


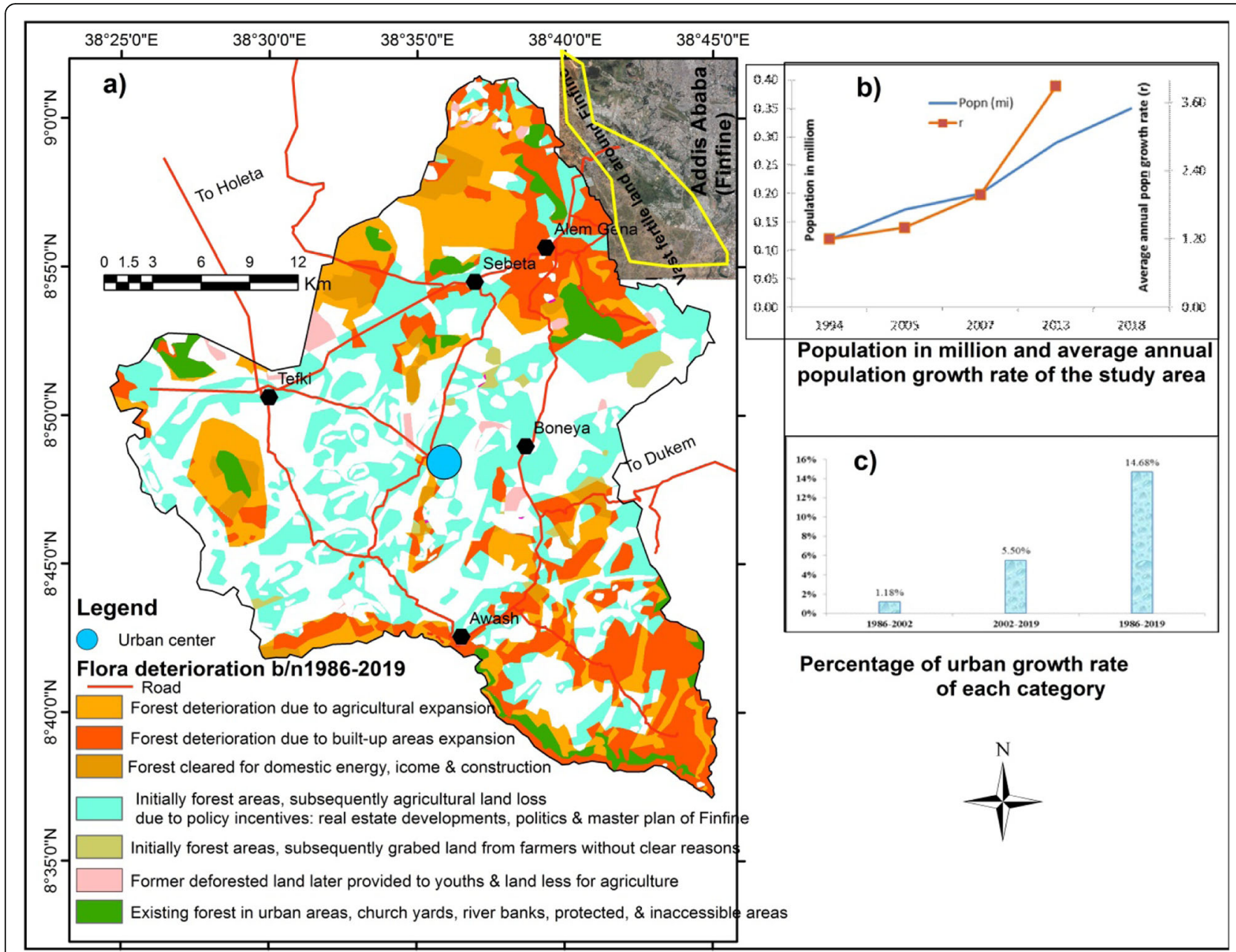

Fig. 3 Forest ecosystem deterioration and fertile land loss and their triggers in the study area (1986-2019)

year (2019). This implies that built-up area concentration around the town center in 1986 later grew to the outer part in 2002 and very swift grown to the outskirt of the town in 2019.

Figure 7 (overall entropy values) and Fig. 8 (zone-wise entropy values) indicated the entropy values for the distribution of the percentage of built-up area for the years 1986, 2002, and 2019. The average entropy value in 1986 was higher in B and G (due to the concentration of built-up areas) while the value has been slightly increased to the outskirt in 2002 and concisely increases to the periphery in 2019 (Fig. 7). The result also indicated that the average entropy values of 0.202 in 1986, 0.589 in 2002, and 0.996 in 2019 which are closer to a lower limit of $\log (n)$ (Fig. 8). The consistent increase in the value of the entropy index indicated that there is an increase in urban sprawl, and development trends to be more dispersed. In 1986, the highest average entropy value was recorded in the southwest $(0.061)$ while the loss was observed in the southeast zone (0.044) and northeast zone (0.043) (Fig. 8 and Table 4). In contrast to the former period, the average entropy value was highest in the southeast $(0.172)$ followed northeast (0.156) while the lowest recorded in the southwest (0.131) and northwest (0.13). This shows that the urban growth trend was shifted from southwest in 1986 to southeast in 2002. Nevertheless, the current urban growth trend (2019) is shifted from southwest to southeast and northeast with an average entropy value of 0.292 and 0.274 , respectively.

\section{Discussion}

Spatial extent, trends, and rates of urban expansions

The study reveals that there is a remarkable urban sprawl in the Sebeta-Awas town, western fringe areas of Addis Ababa, over the past three decades (1986-2019). The built-up area was dominating the gains while forest and agricultural land were dominating the losses and suggesting these changes may have been driven by a combination of biophysical, socioeconomic, and policy 


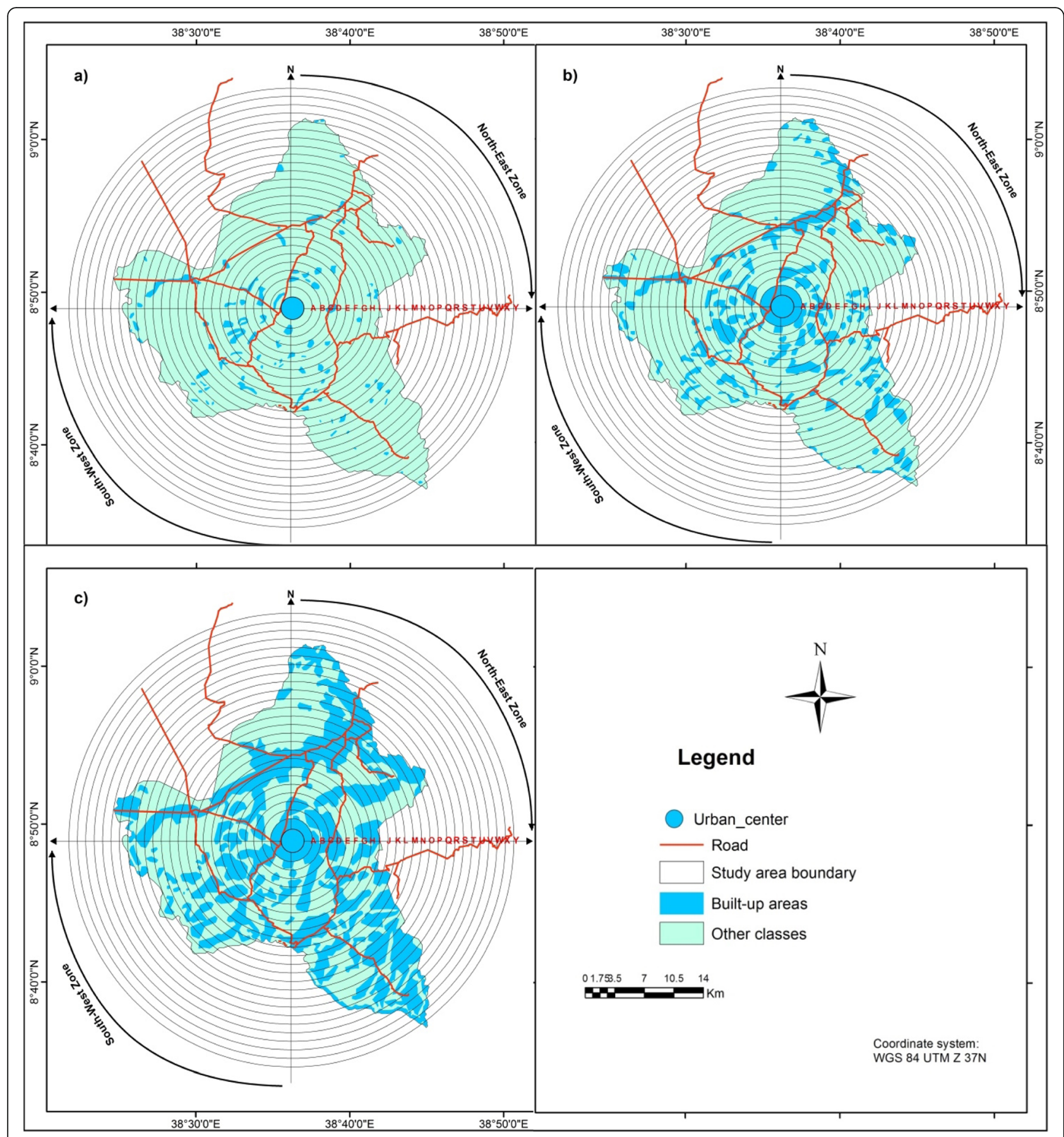

Fig. 4 Built-up areas, concentric rings, and zones of a (1986), b (2002), and c (2019) for Shannon entropy calculation

factors. Rapid urbanization and expansion of settlement (43.12\% net increase) may have further triggered the urban ecosystem, mostly gaining massive areas from agricultural land (25.48\%) and forest (16.66\%) over the past three decades (1986-2019). Though, agricultural land experiences a net loss $(-26.8 \%)$ during the study period it was found to be relatively persistent land cover class (28.45\%).
The former study period (1986-2002) was characterized by a rapid increase in agricultural land due to population growth. A similar study reported that demographic pressure in the urban fringe areas of Addis Ababa resulted in declining landholding size $(\sim 2.4$ ha per household) and the forest was cleared for new settlements and cropland (Deribew and Dalacho 2019). In this regard, $21.4 \%$ of forest land was initially converted to 


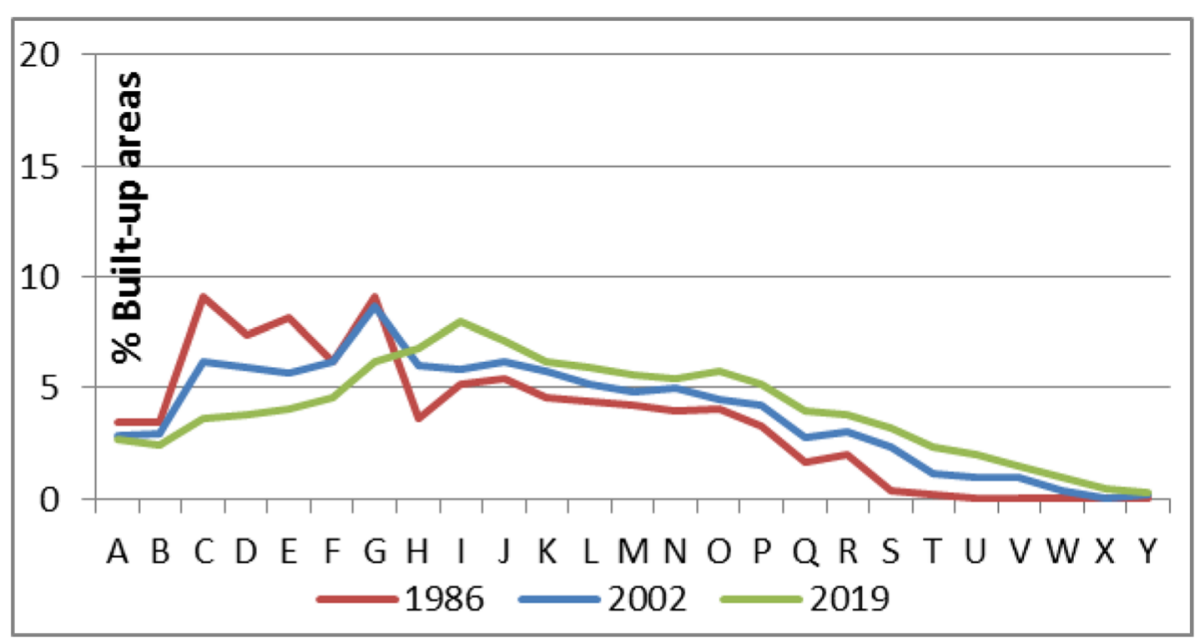

Fig. 5 Percentage of the urban built-up area within each ring

agricultural and this in turn substantially converted to the built-up area (10.17\%). Furthermore, this might be related to nation-wide planned resettlement and villagization/urbanization programs that were carried out by the Ethiopian government (Woube 1995; Getahun et al. 2017; Deribew 2019). The same finding has also been reported at Mordvins in Western Europe that the program resulted in the depletion of biodiversity (Shchankina 2019). Likewise, rural land reform in the mid of 1970s where redistribution of land to landless peasants may have resulted in further fragmentation of forest. The second study period (2002-2019) has returned to the dominance of the built-up area at the expense of mainly agricultural land. The area witnessed the rapid urban sprawl which has increased twice from net mere of $15.21 \%$ during $1986-2002$ to $27.91 \%$ during 2002-2019. The built-up area gained from agricultural land roughly covering $35.17 \%$, of which $10.17 \%$ during $1986-2002$ at an annual rate of $1.2 \%$ and $25 \%$ during 2002-2019 at an annual rate of 5.5\%. The overall built-

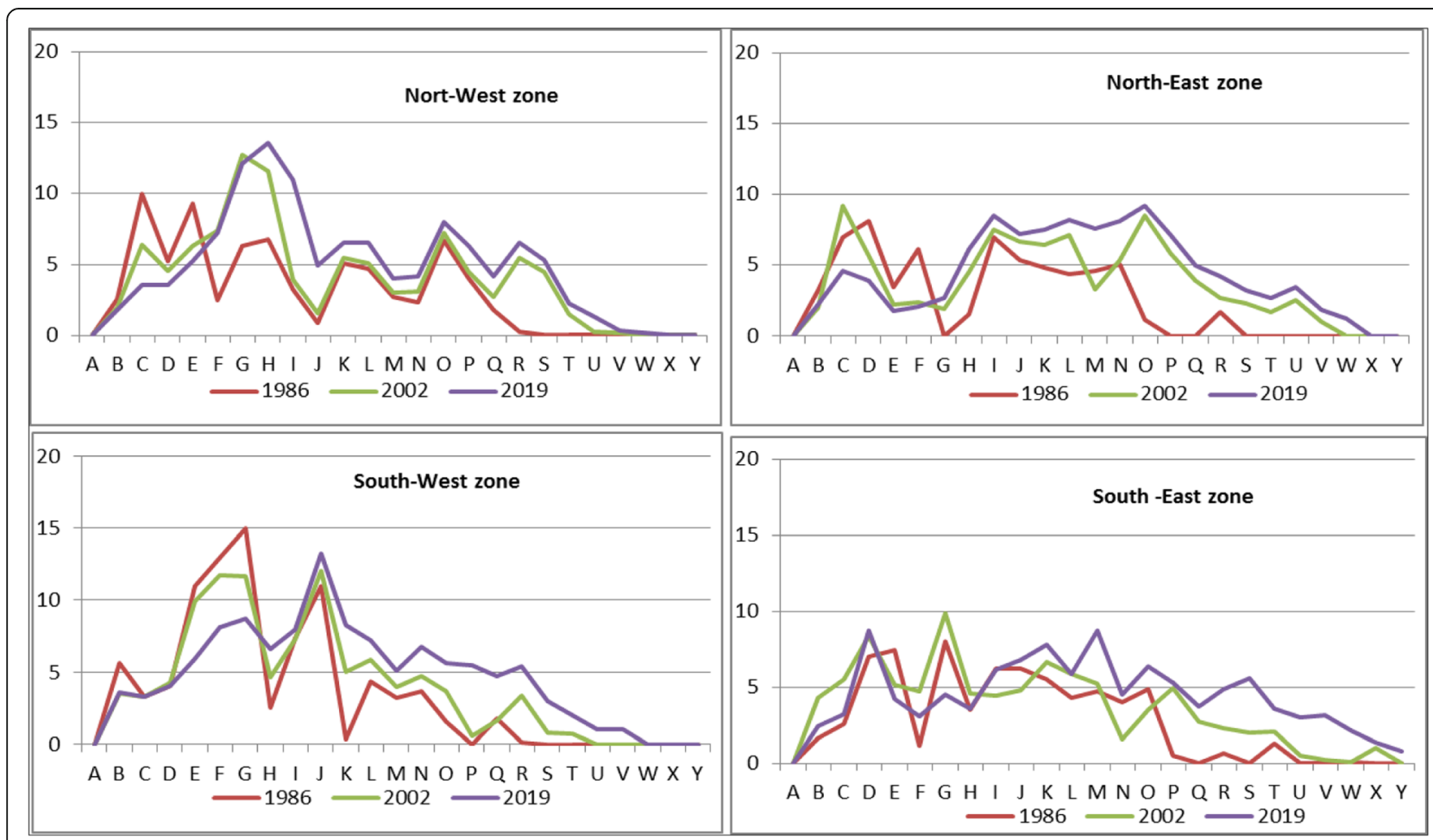

Fig. 6 Percentage of zone-wise distribution of built-up area within each ring 


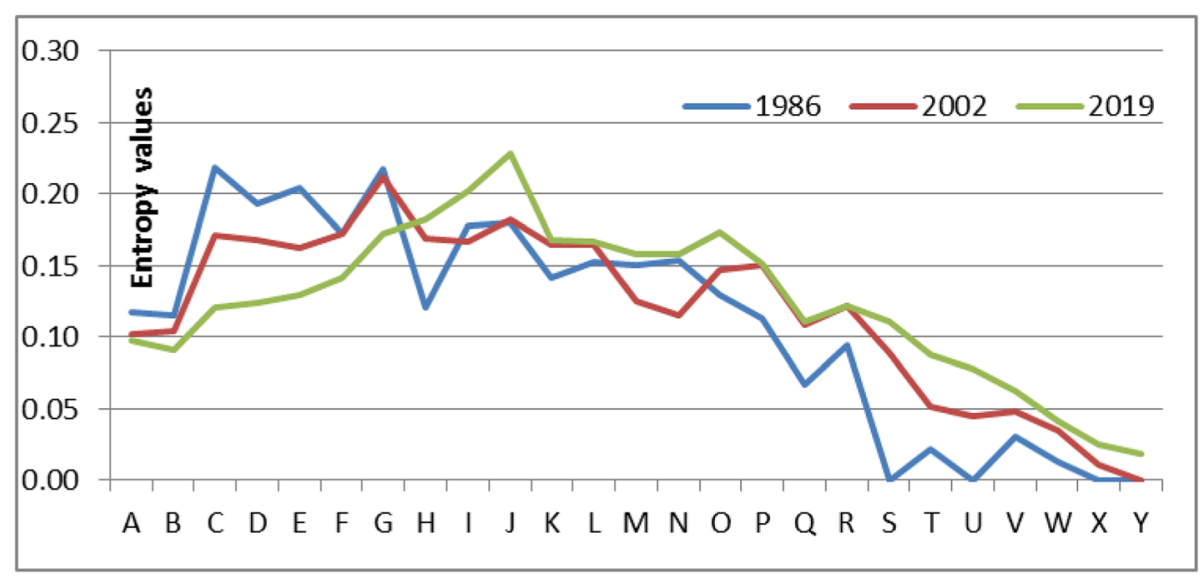

Fig. 7 Distance from the town center and zonal entropy values in each concentric ring

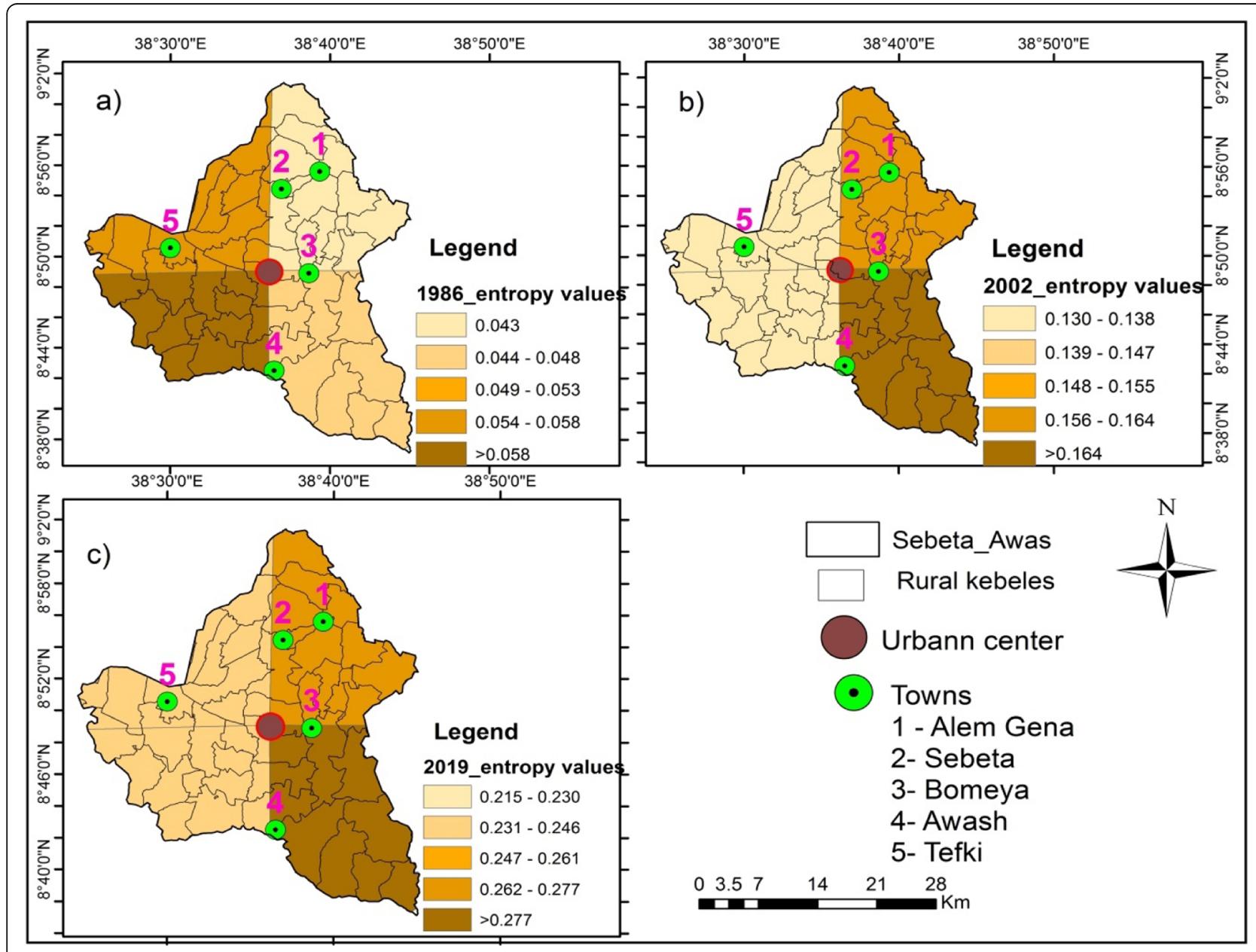

Fig. 8 Zonal entropy values a (1986), b (2002), c (2019) 
Table 4 Zone-wise entropy values in 1986, 2002 and 2019

\begin{tabular}{llllll}
\hline Year & Zones & & & & \\
\cline { 2 - 5 } & Northeast & Northwest & Southeast & Southwest & Total \\
\hline 1986 & 0.043 & 0.054 & 0.044 & 0.061 & 0.020 \\
2002 & 0.156 & 0.130 & 0.172 & 0.131 & 0.600 \\
2019 & 0.274 & 0.215 & 0.292 & 0.216 & 0.996 \\
\hline
\end{tabular}

up area growth in the study area is $\sim 15 \%$ per annum which is five times the country's urban growth. Several triggers such as socioeconomic, demographic, government infrastructure development, and investment policies stimulated massive conversion of fertile land in the study area. Following the replacement of "a neo-liberal" economic development over socialist policy in the early 1990s was among the main catalyst behind transformation was an incentive for local and foreign private investments, expansion of infrastructure, and very rapid urbanization in the study area. The Sebeta-Awas investment office has also confirmed that about 549 household farming community was evacuated from their land during 2007-2010 and compensated cash not more than Birr 39.72 million. The key informants reported that they complained about low consumption and lack of other economic options to make a living. Thus, the majority of the evacuated residents have fled to live informally along the river banks and forest areas, i.e., in the northern and southern edges. In this regard, more than 90.2\% of forest loss due to agricultural encroachment, built-up area expansion, and construction was widely observed in Sebeta and Alem Gena areas, of course, Northeast zone in this study. In this zone, the study showed that carbon density is higher viz. 293 tons/ha in the ecologically protected area (Woldegerima et al. 2017). As to soil erosion features Eucalyptus and Junipers forests which are among the dominant forest cover in the study area found to be aggravated to the soil erosion problem. This has also resulted in eco-hydro depletion which further exposed to environmental disruptions.

\section{The magnitude and shifting of urban growth}

The urban growth patterns observed in the study area align well with the regional biophysical dynamics particularly topography, socioeconomic, and policy changes in the country. These triggered the distribution, concentration, and growth of the built-up areas in the study periods: 1986, 2002, and 2019. A very high concentration of builtup area at an average radius of $6 \mathrm{~km}$ which was very close to the town center ('A' to 'F') observed in 1986 was mainly due to a combination of low demographic pressure, socioeconomic (market), infrastructures, and agricultural landholding security as compared with other study periods. Market, commercial areas, general service areas, and mixed residential areas were relatively found in the town center during the former period. However, later built-up areas were constructed outskirts of the center along with road and river networks, plain area, and fertile land at a rapid rate. As a result, the average entropy increased as one moves away from the center (A); so, the study area experienced a compact built-up area within the radius of 7 $\mathrm{km}$ (till ring ' $\mathrm{H}$ ') in 1986 and it becomes dispersed to the outskirt in the other periods. The average entropy value of 2002 became more than that of the former period by $3 \mathrm{~km}$ (J ring). Similarly, the average entropy value after J ring was very high in the later study period (2019) as compared with the former study period (1986) and middle study period (2002) due to development activities in the peripheral areas. Similar study has also seen in the middle of Nile delta in Tanta and Quttour, where fertile agricultural land decreased by $13.01 \%$ as a result of swift urban expansion during 1972-2005 (Belal and Moghanm 2011).

Similar finding was reported by Dadi et al. (2016) that excessive demand of the land by investors fuelled urban sprawling at the expense of prime agricultural land in the outskirts of the newly industrializing town of Dukem. They have further marked that the number of individual industries grew from less than 50 before the designation of Dukem town as industry zone in 2005, to over 642 units in 2011. Therefore, urban displacement coupled with rapid rural-urban migration to the capital and back to the fringes areas of peri-urban areas of Addis Ababa led to the expansion of built-up areas on cropland and forests were the net losers in peri-urban areas of Addis Ababa (Samson 2009; Leulsegged et al. 2011; Lohnert 2017). Similarly, very rapid urban expansion following the incentive of local and foreign investments, rapid construction and infrastructural developments heightened urban growth rate by $\sim 15 \%$ in 2019 . In this regard, more than $25 \%$ of the study area's agricultural land was replaced by a built-up area during 2002-2019.

Consequently, the average entropy value in 1986 was increased from Tefki town in the northwest and Sebeta town in the northwest to Awash town in the southwest. However, average entropy value due to rapid urban growth was later shifted to the rural peripheries of Sebeta and Alem Gena towns in the northeast in 2002 and this was finally heightened to the east of Awash town, and Boneya town in the southeast zones in 2019. Huge incentive investments in building public houses, industries, horticulture, commercial areas, and other infrastructural developments thereby attracted millions of employees triggered the urban growth. This implies that the satellite town experienced greater dispersal land development mainly between 2002 and 2019. In this regard, as Geopolitics in the landholding system, these investments have been undergoing in the administration of the Oromiya region which led several conflict and peace crises in Finfine Zuria (surrounding). As to 
Deribew and Dalacho (2019) ecologically prioritized areas and fertile land, Finfine Zuria has been substantively converted to built-up areas. Of course, the average entropy of 1986 was one-third of 2002, and later exceptionally escalated in 2019 (Table 4). In this regard, it has been argued that when the entropy value of any later year becomes more than that of the earlier years, greater dispersal of development is indicated (Yeh and Li 2001; Deka et al. 2012). On the other hand, as longs as the entropy values of any study remain less than that of the later years, it indicates compactness of development.

Thus, as the town expanded, residential and mixed residential buildings situated in the town center were disposed to commercial area use, as a result of which people residing in the city center (e.g., in 1986) migrated to the outskirt of the town which was an additional reason for the climax of entropy values mainly in 2019. In the recent years, many real estate developers built very massive new residential and commercial areas, horticulture and huge factories on agricultural lands following major roads in Alem Gena, Awash, Sebeta and Boneya towns, indicating the towns grew in east direction (northeast and southeast) with high sprawling characteristics ( 0.6 entropy value). The crisis was further complicated following the new master plan of Addis Ababa was about to be implemented had dislocated many thousands of people (for investment purpose in Addis) and were settled in the above towns (Fig. 8 and Table 4). This resulted in a remarkable expansion of built-up areas while pressure continued on rural farmland and forest land. The propagations of private investments, horticulture, real estate developers in east Awash, Boneya, Sebeta, and Alem Gena have fascinated a reverse movement of people where urban-rural migration was the main trigger. This was evidenced by rapid urban sprawling by dislocating farming communities (25.48\%) and clearing forest (16.66\%) which grows at an annual rate of $\sim 15 \%$. This may have a far-reaching impact on eco-hydro pollution, urban forest degradation, climate change, ecological deterioration, and economic crisis.

\section{Conclusion}

The applications of GIS, open-source satellite images, and entropy methods reveal that the Sebeta-Awas town has experienced severe reductions in forest and agricultural land due to urban sprawl over the past three decades with the lack of proper development control and management. The main triggers of rapid urban growth were the intermingling of demographic dynamics, government policies (politics on the new master plan of Addis Ababa/ Finfine), biophysical processes, and socioeconomic crisis in the town center. The titanic conversion of peri-urban agriculture, rural farmland, and forest land to the built-up areas may have an impact upon urban ecosystem depletion and economic crisis.

As to ecological deterioration, the remaining dry Afromontane forests are found in an inaccessible area on the west, south, north, and northeast zones of the study area. However, rapid urbanization and the infrastructural network would drive further forfeit due to the livelihood challenges of the recently migrated poor from the rural and urban areas. Hence, forest clearance for cultivation, settlements, domestic energy, and income generation as evidenced by recent urban growth rate $(\sim 15 \%$ per year) may result in total ecosystem depletion on the zones. Local climate change and soil erosion have absolute linkage with the presence and absence of forest resources. To ensure a sustainable supply of ecosystem services and maintain a balanced urban environment, all ecological significant areas in the study area should be ecologically networked and diversified. Therefore, the assessment of ecosystem services provided essential information for effective ecological planning of the existing and potential green areas in terms of species composition and interconnectivity.

The study also implies that the recent government investment policy and infrastructural development have further increased the vulnerability of peri-urban agriculture and rural farmland to built-up population and heightened food insecurity through inflation on the price of crops. Following this, some towns namely, Awash, Sebeta, Alem Gena, Boneya, and Tefki in the zonal rings of the study area have experienced an unusually high degree of urban sprawl due to land speculation. This wave of urban expansion in an anticlockwise thereby rapid urban growth in the study area may result in an economic crisis. Consequently, unstoppable evacuation of farming communities in the fringe areas due to urban expansion is expected to worsen shortly unless hostile policy revision and management actions are undertaken. Therefore, the government officials, planners, and policymakers can use the methods and the results of this study to control and monitor such irregular development patterns for protecting the urban ecosystem and economy by making better use of land resources in the urban fringe areas of Addis Ababa particular for Sebeta-Awas town. Finally, very highresolution satellite imageries due to financial constraints are missed in this study. Therefore, the author directs using very high-resolution imageries conducting future scenarios models from experienced countries would be crucial to conciliate the rapid peri-urban expansions with urban forest ecology and rurral farmland thereby rehabilitate ecological loss in the satellite towns. 


\section{Abbreviations}

CSA: Central Statistical Authority; FZSeP: Finfine Zone Socio-Economic Profile; GIA: Geospatial Information Agency; GIS: Geographic Information System; LULC: Land use and land cover

\section{Acknowledgements}

The author thanks local elders and youths, and urban experts of Sebeta town who helped during field data collection and provide their views. I also thank the two anonymous reviewers and editor in the Journal of Ecological Processes for their priceless and constructive comments. The author is also greatly indebted to thank the USGS for offering free access to Landsat imageries.

\section{Author's contributions}

KT has designed the study, collected all data, carried out fieldwork, analyzed satellite imageries, and interpreted the document of the manuscript. Moreover, KT has contributed all literature work, reviewing, and editorial works. Therefore, $\mathrm{KT}$ is the only author of this manuscript. All author(s) read and approved the final manuscript.

\section{Availability of data and materials}

All data are included in the manuscript.

\section{Ethics approval and consent to participate}

Not applicable.

\section{Consent for publication}

I agreed to publication in the journal of Ecological Processes.

\section{Competing interests}

The author declares that he has no competing interests.

Received: 13 March 2020 Accepted: 4 August 2020

Published online: 07 September 2020

\section{References}

Abebe MS, Deribew KT, Gemeda DO (2019) Exploiting temporal-spatial patterns of informal settlements using GIS and remote sensing technique: a case study of Jimma city, Southwestern Ethiopia. Environ Sys Res 8:6. https://doi. org/10.1186/s40068-019-0133-5

Abrha AM, Nigus HK, Weldetensae GB, Tilahun M, Nigusse AG, Deribew KT (2017) Effects of human disturbances on two sympatric francolin species in the Central Highlands of Ethiopia. Podoces 12(1):13-22

Alig RJ, Healy RG (1987) Urban and built-up area changes in the United States: an empirical investigates of determinants. Land Econ 63:215-226. https://doi. org/10.2307/3146831

Anderson BJ, Hardy EE, Roach JT, Witmer RE (1976) A land use and land cover classification scheme for use with remote sensor data. https://doi.org/10. 3133/pp964

Belal AA, Moghanm FS (2011) Detecting urban growth using remote sensing and GIS techniques in Al Gharbiya governorate, Egypt. Egypt J Remote Sens Space Sci 14:73-79 https://doi.org/10.1016/j.ejrs.2011.09.001

Central Statistical Authority (CSA) (2015) Population projection of Ethiopia for al regions at Wereda level from 2014-2017. Central Statistical Agency, Addis Ababa

Chander G, Markham BL, Hedler DL (2009) Summary of current radiometric calibrations coefficient for Landsat MSS, TM, ETM+ and EO-1 ALI sensors. Remote Sens Environ 113:893-903. https://doi.org/10.1016/j.rse.2009.01.007

Cheng J, Masser I (2003) Urban growth pattern modeling: a case study of Wuhan city, PR China. Landscape Urban Plan 62(4):199-217. https://doi.org/10.1016/ S0169-2046(02)00150-0

Congalton RG, Green K (2009) Assessing the accuracy of remotely sensed data: principles and practices, 2nd edn. CRS Press, Boca Raton, Florida. https://doi. org/10.1016/j.jag.2009.07.002

Dadi D, Azadi H, Senbeta F, Abebe K, Therif F, Stellmacher T (2016) Urban sprawl and its impacts on land use change in Central Ethiopia. Urban For Urban Green 16:141-132. https://doi.org/10.1016/j.ufug.2016.02.005

Deka J, Tripahi OP, Khan ML (2012) Urban growth trend analysis using Shannon Entropy approach — a case study in North-East India. Int J Geomat Geosci 2(4):1062-1068
Deribew KT (2019) Spatially explicit statistical modeling of random and systematic land cover transitions in the main grassland plain of Nech Sar National Park, Ethiopia. Ecol Process 8:46. https://doi.org/10.1186/s13717-0190199-z

Deribew KT, Dalacho DW (2019) Land use and forest cover dynamics in the North-eastern Addis Ababa, central highlands of Ethiopia. Environ Syst Res 8 : 8. https://doi.org/10.1186/s40068-019-0137-1

Friis DS, Breugel P (2010) Atlas of the potential vegetation of Ethiopia. Royal Danish Academy of Sciences and Letters, Copenhagen, pp 8-14

Finfine Zone Socio-economic Profile (FZSeP) (2011) Demographic and Socioeconomic Population in Finfine Special Zone, Addis Ababa, Ehtiopia, pp $1-68$

Getahun K, Poesen J, Rompaey AV (2017) Impacts of resettlement programs on deforestation of moist evergreen Afromontane forests in Southwest Ethiopia. Mt Res Dev 37(4):474-486. https://doi.org/10.1659/MRD-JOURNAL-D-15-00034.1

Kamusoko C, Gamba J (2015) Simulating urban growth using random forestcellular automata (RF-CA) model. ISPRS Int J Geo-Inf 4:447-470. https://doi. org/10.3390/ijgi4020447

Kiamba A (2012) The sustainability of urban development in developing economies. Consilience 8(1):20-25. https://doi.org/10.7916/D8XD11C8

Kumar JA, Pathan SK, Bhanderi RJ (2007) Spatio-temporal analysis for monitoring urban growth - a case study of Indore city. J Indian Soc Remote Sens 35(1): $11-20$

Landis JR, Koch GG (1977) The measurement of observer agreement for categorical data. Biometrics 33(1):159-174 https://doi.org/10.2307/2529310

Leulsegged K, Zeleke G, Fitsum H, Andreas H (2011) Impact of urbanization of Addis Ababa City on peri-urban environment and livelihood. https://doi.org/ 10.1021/ja01497a062

Liao JF, Jia YQ, Tang LN, Huang QL, Wang YY, Huang N, Hua LZ (2018) Assessment of urbanization-induced ecological risks in an area with significant ecosystem services based on land use/land cover change scenarios. Int J Sust Dev World Ecol 25:448-457. https://doi.org/10.1080/ 13504509.2017.1415234

Lillesand TM, Kiefer RW, Chipman J (2008) Remote sensing and image interpretation, 6th edn. Wiley and Sons, Inc., New York

Liu W, Xu J, Li J, Li S (2019) Rural households' poverty and relocation and settlements: Evidence from Western China. Int J Environ Res Public Health 16 2609. https://doi.org/10.3390/ijerph16142609

Lohnert B (2017) Migration and the Rural-Urban Transitions in Sub-Saharan Africa. Centre for Rural Development (SLE), Berlin, pp 1-78

Minta M, Kibret K, Thorne P, Nigussie T, Nigatu L (2018) Land use and land cover dynamics in Dendi-Jeldu hilly-mountainous areas in the Central Ethiopian highlands. Geoderma 314:27-36 https://doi.org/10.1016/j.geoderma.2017.10.035

Mohamed A, Worku H, Kindu M (2019) Quantification and mapping of the spatial landscape pattern and its planning and management implications: a case study in Addis Ababa and the surrounding area, Ethiopia. Geol Ecol Landscapes. https://doi.org/10.1080/24749508.2019.1701309

PCC (Population Census Commission) (2008) Summary and Statistical Report of the 2007 Population and Housing Census: Population Size by Age and Sex. PCC, Federal Democratic Republic of Ethiopia, Addis Ababa

Puertas OL, Henriquez MFJ (2014) Assessing spatial dynamics of urban growth using an integrated land use model. Application in Santiago Metropolitan area, 2010-2045. Land Use Policy 38:415-425. https://doi.org/10.1016/j. landusepol.2013.11.024

Puyravaud JP (2003) Standardizing the calculation of the annual rate of deforestation. Forest Ecol Manage 177(1):593-596. https://doi.org/10.1016/ S0378-1127(02)00335-3

Rahman A, Aggarwal SP, Netzband M, Fazal S (2011) Monitoring urban sprawl using remote sensing and GIS techniques of a fast growing urban Centre, India. IEEE J Sel Top Appl Earth Observ Remote Sens 4(1):56-64. https://doi. org/10.1109/JSTARS.2010.2084072

Richter R, Schlapfer D, Muller A (2006) An atmospheric correction algorithm for visible/NIR imagery. Int J Remote Sens 27(10):2077-2085. https://doi.org/10. 1080/01431160500486690

Rosell S, Olvmo M, Holmer B (2017) Cultivated land - a scarce commodity in a densely populated rural area in South Wollo, Ethiopia. J Land Use Sci 12:252270. https://doi.org/10.1080/1747423X.2017.1319978

Samson K (2009) Squatter settlement and the issue of regulation: a case of Dire Dawa, Ethiopia. Local Governance Dev J 3(1):55-66

Shchankina LN (2019) Mordvins in Western Siberia in the late 19th to early 20th century: certain issues in the migration and settlement. J Archaeol Ethnol 
Anthropol Eurasia 47(3):119-126. https://doi.org/10.17746/1563-0110.2019.47. 3.119-126

Shenbagraj N, Kumar MN, Stalin JL (2019) Assessment of urban growth using Shannon's Entropy Index: A case study of Chennai, Detroit of India. J Appl Nat Sci 11(2):281-284 https://doi.org/10.31018/jans.v11i2.2037

Singh B (2014) Urban growth using Shannon's entropy: a case study of Rohtak City. Int J Adv Remote Sens GIS 3(1):544-552. http://technical.cloud-journals. com/index.php/IJARSG/article/view/Tech-237

Singh A, Maithan S, Begum A, Kumar V (2019) Analysis of the urban sprawl dynamics using Shannon's entropy in RooRkee planning area. Int J Tech Innov Model Eng 5(2):1-11

Soubbotina PT (2004) Beyond Economic Growth. An Introduction to Sustainable Development, 2nd edn. The World Bank, New York, p 205

Subasinghe S, Estoque RC, Murayama Y (2016) Spatiotemporal analysis of urban growth using GIS and remote sensing: a case study of the Colombo Metropolitan area, Sri Lanka. ISPRS Int J Geo-Inf 5:197. https://doi.org/10. 3390/ijgi5110197

Sudhira HS, Ramachandra TV, Jagadish KS (2004) Urban sprawl: metrics dynamics and modeling using GIS. Int J Appl Earth Obs Geoinf 5(1):29-39. https://doi. org/10.1016/j.jag.2003.08.002

Teillet PM, Guindon B, Goodenough DG (1982) On the slope-aspect correction of multispectral scanner data. Can J Remote Sens 8(2):84-106. https://doi.org/ 10.1080/07038992.1982.10855028

Teller C, Assefa H (2010) The demographic transition and development in Africa: the unique case of Ethiopia; caution regarding existing forecasts. J World Dev 32(1):23-51 https://doi.org/10.1007/978-90-481-8918-2

United Nations (2015) Transforming our world: the 2030 Agenda for Sustainable Development. United Nations, New York

Vermote EF, Saleous NZ (2006) Operational atmospheric corrections of MODIS visible to middle infrared land surface data in the case of an infinite Lambertian target. In: Qu JJ, Gao W, Kafatos M, Murphy RE, Salomonson W (eds) Earth Science Satellite Remote Sensing: Science and Instruments. Springer, Berlin: pp 123-153. https://doi.org/10.1007/978-3-540-37293-6_8

Wakode BH, Baier K, Jha R, Azzam R (2014) Analysis of urban growth using Landsat TM/ETM data and GIS - a case study of Hyderabad, India. Arab J Geosci 7:109-1210. https://doi.org/10.1007/s12517-013-0843-3

Wang HW, Zhu LC, Zhao CY, Zheng SN (2018) Urban ecological risk assessment management platform. Int J Sust Dev World Ecol 25(7):1-6. https://doi.org/ 10.1080/13504509.2018.1425934

Woldegerima T, Yeshitela K, Lindley S (2017) Ecosystem services assessment of urban forests of Addis Ababa, Ethiopia. Urban Ecosyst 20(3):683-699. https:// doi.org/10.1007/s11252-016-0624-3

Woube M (1995) Southward-Northward resettlement in Ethiopia. Northeast Afr Stud 2(1):85-106 https://doi.org/10.1353/nas.1995.0011

Yeh AGO, Li X (2001) Measurement and monitoring of urban sprawl in a rapidly growing region using entropy. Photogramm Eng Remote Sens 67(1):83-90

\section{Publisher's Note}

Springer Nature remains neutral with regard to jurisdictional claims in published maps and institutional affiliations.

\section{Submit your manuscript to a SpringerOpen ${ }^{\mathcal{O}}$ journal and benefit from:}

- Convenient online submission

- Rigorous peer review

- Open access: articles freely available online

- High visibility within the field

- Retaining the copyright to your article

Submit your next manuscript at $\boldsymbol{\nabla}$ springeropen.com 